\title{
3 光刺激イオン脱離反応
}

持地広造

1 はじめに

光照射により表面を構成する原子や吸着種がイオンと なって放出される現象は光刺激イオン脱離（Photonstimulated Ion Desorption；PSD）と呼ばれてい る ${ }^{1.2)}$. PSD は光励起によるエッチングや薄膜堆積など の化学反応の素過程となっており，これらのプロセス開 発の重要な鍵をにぎっている。さらに，PSDを表面計 測の立場加見ると，検出されるイオンの大部分が表面 最上層の原子あるい你分子が脱離したものてあるため， 表面感度が極めて高いこと，ならびに，残留がスなどの バックグランドの影響が少なく， $\mathrm{S} / \mathrm{N}$ が高いことが挙 げられる.PSDにおけるイオンの脱離機構に関しては, 基板の種類 (金属, 半導体, 絶縁体など) や光の波長に 応じてさまざまのモデルが提案されている，放射光のよ うな波長の短い光を照射した場合は, 表面原子の内殻電 子が励起され，これに続く Auger 電子緩和により複数 の正孔が発生しこれにより生じるイオン間のクーロン反 発力あるいは多数正孔の局在による不安定化か原因となっ

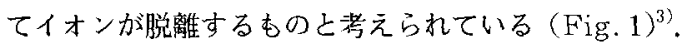
筆者らは，デジタルプロセスなど原子オーダーの表面構 造制御への応用の可能性を探るべく, 光刺激イオン脱離 の検討を進めている。ここでは Si 表面を中心にイオン の脱離特性に及ぼす表面原子結合状態の影響に関して, これまでに得られている結果を紹介し, 光刺激イオン脱 離の特徴と今後の展望について述べる.

\section{2 光刺激脱離オオンの計測方法}

脱離イオンの計測のための装置構成を Fig. 2 に示す. 脱離イオン種の同定には四重極質量分析計を用いており， 特に, 微量な脱離イオンを検出するためにパルスカウン ト方式を採用している，また，脱離イオンを四重極に効 率よく取り这むために試料に適当なバイアスをかけるな ぞ, 試料と分析計入り口付近の電位関係に注意を払って いる.

脱離イオンのもう一つの訫測手段として, 特に, 脱離 イオンの初期の運動エネルギーを調べる目的から，イオ ンの飛行時問計测装置 (TOF) を導入している。この 場合, 通常の放射光ではパルス間隔が非常に短く, 飛行 時間計測が困難であるため, シンクロトロンを周回して いる電子の群れ（バンチ）の数を堿らすことにより(一

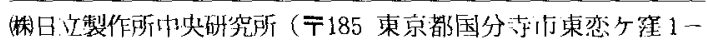
280)
般には，バンチ数を 1 にする)，放射光のパルス間隔を 長くしている. 高エネルギー物理学研究所の放射光実験 施設の場合, このシングルバンチモード運転により，放 射光のパルス間隔を通常の $2 \mathrm{~ns}$ から $624 \mathrm{~ns}$ まで延ばし ている.このシンダルバンチモードで運転されているシ ンクロトロンの高周波加速器のパルス信号と検出器に到 達したイオン信号の時間差を電压に变換し, 脱離イオン の飛行時間スペクトルを测定している.

\section{3 イオンの脱離効率に及ぼす表面結合 状態の影響}

Fig. 3 は $50 \%$ HF（フッ化水素）水溶液で洗浄し た Si (111）表面に放射光（んレ〜1.5 keV を最大強度と する連続光）を照射した時の脱離イオンの質量スペクト ルである. 主な脱離イオンとして $\mathrm{H}^{+}$と $\mathrm{F}^{+}$が観測され ている、ここで，あら加じめSi 表面を水素原子（ラシ カル）に曝してから放射光を照射した場合， $\mathrm{O}^{+}$の脱離 量が飛躍的（３0 倍）に増加する．水素原子は電子衝 撃加熱で高温 ( $\left.1700^{\circ} \mathrm{C}\right)$ にしたW パイプ中に水素ガ スを流すことにより生成したものを利用している。同様

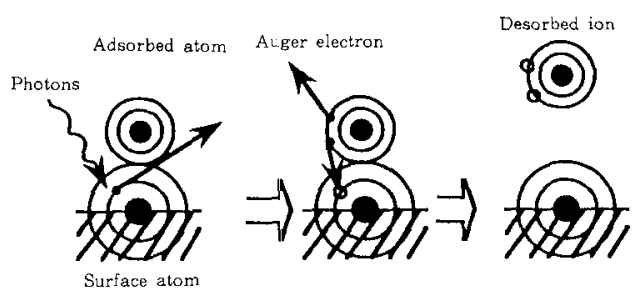

Fig. 1 Schematic representation for photonstimulated ion desorption.

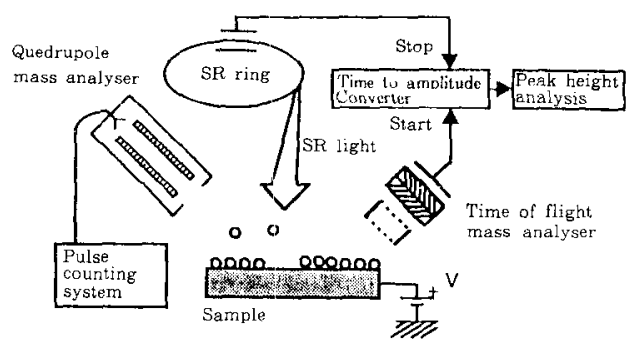

Fig. 2 Block diagram of experimental setup for PSD by synchrotron radiation. 


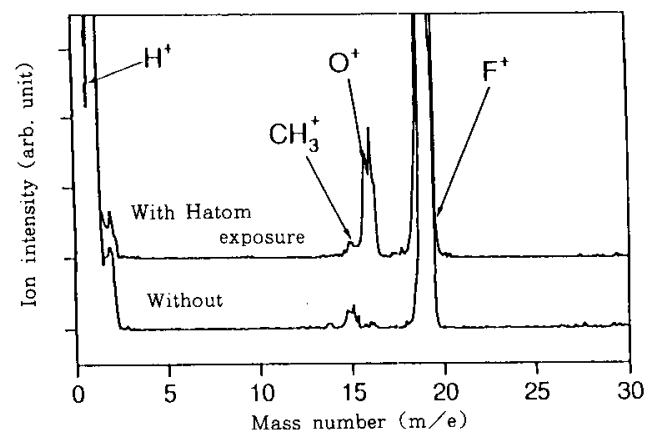

Fig. 3 Mass spectra of PSD ions from HF-rinsed Si (111) surface.

の現象は熱酸化した Si 表面でも顕著に観測されており， この場合には水素原子処理により， $\mathrm{O}^{+}$の脱離量は約 200 倍に増加する (Fig. 4).こ扎らの $0^{+}$脱離の増加は 水素原子処理により表面の-Si-O-Si-結合がーSi$\mathrm{O}-\mathrm{H}$ 結合に変わったため, 酸素原子が光脱離しやすく なったものと解釉されている.すななお，イオンの脱離 は表面原子の電子状態の励起により引き起こされるもの であり，励起状態が他の緩和過程に移行する前に脱離が 起こる必要がある.したがって, $-\mathrm{Si}-\mathrm{O}-\mathrm{Si}-$ のう な架橋型の結合の場合には酸素原子が脱離するためには, $2 つ の \mathrm{Si}-\mathrm{O}$ 結合が同時に切断ざれる必要があり，その 反応確率は小さいと考えられる。一方, $-\mathrm{Si}-\mathrm{O}-\mathrm{H}$ 結 合の場合は，質量スペクトルに $\mathrm{OH}^{+}$が観測されていな いことから，まず, 優先的に水素原子が $\mathrm{H}^{+}$として脱離 した後, $\mathrm{Si}-\mathrm{O}$ 結合が切断されて $\mathrm{O}^{+}$か脱離したものと 考えられる.これらの実験結果は, 同じ種類の原子であっ ても，表面におけるその原子の結合状態によって，その 原子がイオンとして脱離する効染が大きく異なることを 示すあのである.

\section{4 脱離イオンの運動エネルギーに及ぼす表面 結合状態の影響}

脱離イオンの脱離初期にお゙りる運動エネルギーには脱 離イオンの表面における結合状態, ならびに光励起過程 などに関する情報が含まれているものと考えられ，これ を測定することはイオンの脱離機構を調べるうえで極め て重要である．運動エネルギーの測定は，脱離イオンの 飛行時間計測により行っている. Fig. 5 は, Si (100) を購入してそのままのものと, $10 \%$ DF 水溶液で洗 净したものの 2 種類の表面に分光した放射光（h $\nu=$ $550 \mathrm{eV}$ )を照射したときに観測された脱離イオンの飛 行時間スペクトルである ${ }^{4)}$.ここで，未処理の Si 表面 からは単一のピークのみが観測されているが, HF 処理 を行った表面からは，新たに，もう一本の遅いピークが

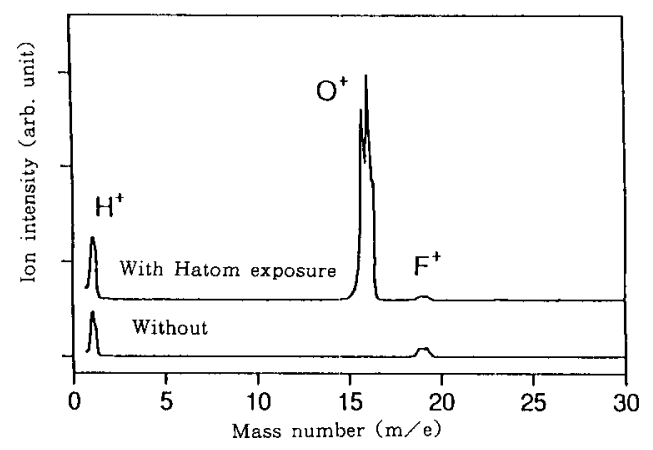

Fig. 4 Mass spectra of FSD ions from thermally oxidized $\mathrm{Si}(111)$.

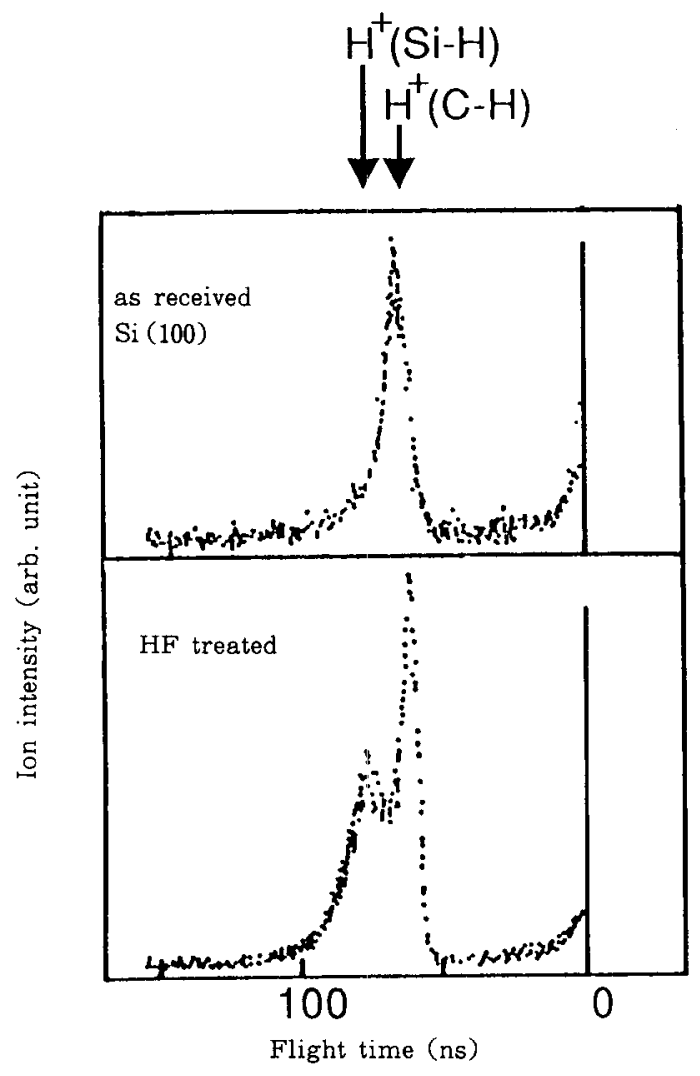

Fig. 5 TOF spectra of PSD ions from Si (100) surfaces.

観湘されている，試料表面々飛行管の間の電位差を变え てイオンの飛行時間变化を測定することにより，これら

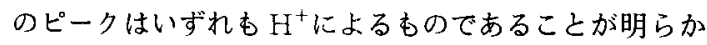
にされている.一般に，未処理の Si 表面は自然酸化膜 や炭化水素の吸着層で覆われているが, HF 水溶液で洗 浄すると自然酸化膜は溶解除去されて Si 表面は水素原 
子で終端されるようになる5).ただし，炭化水素の大部 分は除去されずに残る．以上の様子はこれらの試料表面 を光電子分光により解析した結果から屯確認されている. したがって，Fig. 5 の飛行時間スペクトルにおいて， 飛行時間が短い（運動エネルギーが大きい）方のピーク は $\mathrm{C}-\mathrm{H}$ 結合から脱離しだ $\mathrm{H}^{+}$，また，飛行時間が長い （運動エネルギーが小さい）方のピークは $\mathrm{Si}-\mathrm{H}$ 結合か ら脱離した $\mathrm{H}^{+}$に対応するものと推定される，すなわち， 結合状態の違いが脱離イオンの初期運動エネルギーの差 (今の場合, 約 $55 \mathrm{eV}$ ) に反映されたものでありこの ことは光刺激脱離イオンの計測から最上表面倞子の結合 状態に関する情報が得られる可能性を示すものである. 但し，現状ではこの運動エネルギーの差が具体的に結合 状態の何の違いに由来するのかは不明であり, 今後, よ り多くの種類の結合状態について脱離イオンの運動エネ ルギーを測定することにより，この点を明らかにしてい く必要がある。

\section{5 物理吸着状態における光刺激イオン脱離}

放射光を用いたエッチングでは, $\mathrm{Si} よ り \mathrm{SiO}_{2}$ のエッ チング速度が著しく速いなど, 従来のプラズマ利用エッ チングでは見られない材料選抧性が報告されている ${ }^{6,7)}$. このようなエッチング特性にはエッチングガス分子と材 料表面の放射光励起反応が深く関わっているものと考艺 られる。Fig. 6 は， $\mathrm{SF}_{6}$ 分子を $\mathrm{Si}$ および $\mathrm{SiO}_{2}$ 表面に 低温吸着させた表面に放射光（hレ〜1.5 keV を最大強 度とする連続光)を照射した時の脱離イオンを計測した あのである.ここで， $\mathrm{SiO}_{2}$ 表面では $\mathrm{SiF}^{+} や \mathrm{SO}^{+}$など $\mathrm{SF}_{6}$ との反応生成物イオンが観测されているが， $\mathrm{Si}$ 表 面ではこれらのイオンは全く検出されていない，すなわ ち, 上述のエッチング特性に対応した結果が得られてい る.この反応性の違いの要因として, 放射光励起により $\mathrm{SF}_{6}$ が解離して生成された $\mathrm{S}^{+} や \mathrm{~F}^{+}$が, $\mathrm{Si}$ 上り結合極 性の大きい $\mathrm{SiO}_{2}$ と反応しやすいことが考元られる。 た, $\mathrm{SiO}_{2}$ のほうが $\mathrm{Si}$ に比べて放射光に上る励起効果 (結合切断など) が大きいことも反応の選択性に影響し ているものと推定される.

\section{6 おわりに}

光刺激イオン脱離に及ばす表面状態の影響について述 べた。すでに明らかなように同一の脱離イオン種であっ ても, その脱離効率ならびに運動エネルギーは脱離イオ ンの表面に扔ける結合状態によって著しく变化する。こ

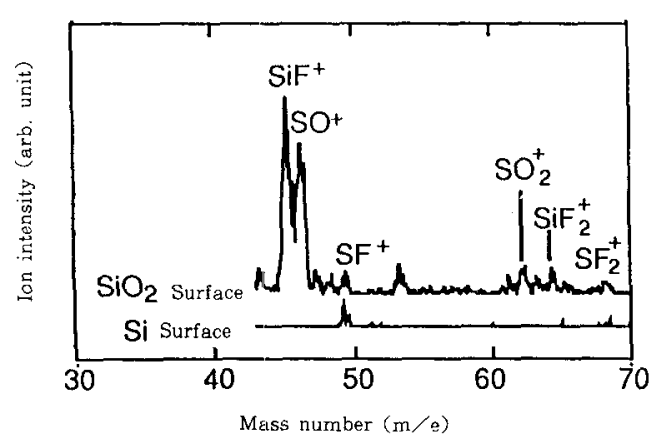

Fig. 6 Mass spectra of PSD ions from physically $\mathrm{SF}_{6}$-adsorbed surfaces.

れらの現象は, 光吸収に上り生成される励起状態の寿命 や内部エネルギーの大きさが表面原子の結合状態に深く 関わっているためと考元られる。したがって, 今後, 表 面に何らかの適当な化学種を吸着させて表面原子の結合 状態を制御し，これに波長を選択した光を照射すること により, 表面の原子層をデジタル的にエッチングするこ とも可能になるものと期待される.

本稿で述べた研究の一部は高エネルギー物理学研究所 との協定研究（課題番号 91-020，91-014）で行われたも のであり, 高エネ研放射光実験施設の関係各位に深く感 謝申し上げます，また，共同研究者の落合勲，小川太郎， 山本清二の各氏（侏日立製作所中央研究所）に感謝いた します.

\section{文献}

1) C.-R. Wen and R.A. Rosenberg, J. Vac. Sci. Technol., A 8(3), 2710 (1990).

2) D.M. Hanson, R. Stockbauer and T.E. Madey, Phys. Rev., 24, 5513 (1981).

3) M.L. Knotek and P.J. Neibelman, Phys. Rev. Letl., 40, 964 (1978).

4) K. Mochiji, K. Lee, C.I. Ma, I).Y. Kim, M. Mahalingam, Г.). Ilanson and E.D. Johnson, J. Appl. Phys., 72, 4156 (1992).

5) T. Takahagi, I. Nagai, A. Ishitani, 11. Kuroda and Y. Nagasawa, J. Appl. Phys., 64, 3516 (1988).

6) T. Urisu and H. Kyuragi, J. Vac. Sci. Tech., B 5, 1436 (1987).

7) T. Ogawa, 1. Ochiai, S. Yamamoto, K. Mochiji and K. Tanaka, Digest of Papers 5 th Int. Microprocess Conf. (Kawasaki), 186 (1992). 